\title{
Differences in Race and Gender of 6th Grade Science Students' Endocrine System Test Scores 從種族和性別角度分析六年級科學生的内分泌系統测試分值差異
}

Jonell PEDESCLEAUX

Morehouse College,

Atlanta, GA, U.S.A.

Jiangong TAN

Department of Leisure and Sports Management, Guangzhou Sport University,

Guangzhou, CHINA

\section{吉耐爾 帕蒂斯格魯}

美國佐治亞州

亞特蘭大莫爾豪斯學院

\section{譚建共 \\ 中國廣州體育學院休閒體育與管理系}

\section{Wanda MARTINEZ}

Waterloo Community Schools District, Waterloo, IA, U.S.A.

\section{Janet McClAIN}

Multicultural Initiatives in Teaching Program, University of Northern Iowa, Cedar Falls, IA, U.S.A.

\section{旺薘 馬丁内斯}

美國愛荷華州

滑鐵盧社區學校

基耐特 麥克萊恩

美國北愛荷華大學

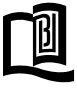

\begin{abstract}
This quantitative study measured endocrine system pre- and post-test scores of 77 sixth grade science students at a Midwestern middle school. Results indicated higher post-test science scores and differences in scores by race. It was concluded that middle school students differ in their level of understanding of life science information.
\end{abstract}

KEYWORDS: Endocrine System, Race, Gender, Middle School Students.

\section{摘 要}

用定量研究的方法對美國中西部77名六年級科學科中學生的成績, 進行先期測試和事後測試。測試結果顯示: 事後測試的分 值較高，而且種族之間分值差異較大。由此推斷，中學生在理解生命科學資訊水準上存有一定差異。

關鍵字：內分泌系統，種族，性別，中學生

\section{Introduction}

Life science can be viewed as learning by experience. All students are science learners and must be made aware of their use of science in their everyday lives. Measuring student achievement in science has been a major subject of debate for many years due to low student test scores. Many school administrators and educational activists believe that public education must 
make higher student test scores a part of school academic success. Science educators have long been concerned that many students fail to engage in academic tasks with the goal of achieving better understanding of science (Lee \& Anderson, 1993). Assessment of student performance exerts extraordinary influence on the lives of children and their families and on every level of the education system. If used properly, good assessment can be a powerful catalyst for improving both curriculum and instruction. Poor assessment practices, on the other hand, can impoverish our expectations for learning science, focusing teachers' and students' efforts on less important concepts and skills or on test taking as an end itself (Stern \& Ahlgren, 2002). Chen and Parjares (2010) states, "when students transition to middle school there tends to be a shift towards the belief that those who succeed with working hard must be the smart ones, and if someone has to put forth a considerable amount of effort it must be a sign of some deficit in ability. Examining students in middle school science classrooms can, therefore, provide important insights into the development of students' beliefs about science ability and about scientific knowledge" (p. 77).

Iowa is one of several states that do not follow the National Science Education Standards (NSES). Iowa's science content standards are based on the Scope, Sequence and Coordination (SS\&C) project. According to Yager and Weld (1999), "The Scope, Sequence and Coordination (SS\&C) project is about transforming peoples' beliefs to promote lasting change in science education. $\mathrm{SS} \& \mathrm{C}$ is a major reform initiative in the United States conceived by the National Science Teachers Association (NSTA) with major funding by the National Science Foundation (NSF). The original funding in 1990 resulted in six state projects in: Alaska, Iowa, California, North Carolina, Puerto Rico and Texas. The six projects utilized quite different approaches to meet the common national goals and anticipated outcomes of the project" (p.170). According to The National Research Council (1996), the NSES and the Iowa SS\&C projects both broaden the definition for school science. For example, the final NSES document identifies eight facets of science content, namely: (1) Science as Inquiry, (2) Physical Science, (3) Life Science, (4) Earth and Space Science, (5) Science and Technology, (6) Science in Personal and Societal Perspectives, (7) History and Nature of Science, and (8) Unifying Concepts and Processes (Yager \& Weld, 1999, p. 172). The current science standards for Iowa are (1) Students can understand and apply skills used in scientific inquiry, (2) Students can understand concepts and relationships in life science, (3) Students can understand concepts and relationships in Earth/space sciences, and (4) Students can understand concepts and relationships in physical science (Iowa Department of Education, 2010). This study conducts an evaluation of the endocrine system, which addresses Iowa Science Standard 2: Students can understand concepts and relationships in life science.

The purpose of this study was to measure endocrine system pre- and post-test scores of sixth grade middle school science students during the 2009 - 2010 school year. The school, located in a Midwestern state, had a total enrollment of 187 sixth grade students with an average class size of 22.2 students. The demographics of the Midwestern middle school were 32\% African-American, $56 \%$ White, $7 \%$ Hispanic and $1 \%$ Asian. Four percent of the students self-identified themselves as Multi-Racial. The percentage of students on free or reduced lunch at this Midwestern middle school was $72.12 \%$.

This study proposes (1) There is no significant difference in pre-and post-test scores of science students, (2) There is no significant difference in pre-and post-test scores of science students by race, and (3) There is no gender difference in pre-and post-test scores of science students. "Tests are sets of questions or activities that measure your knowledge or abilities in particular areas or subjects. Tests have always been a regular part of school life. For students, tests are opportunities to show how much they know or how much they have learned. For teachers, tests measure student comprehension and guide future instruction” (Bose, 2005).

A number of studies have been conducted to determine gender differences in science classrooms at the national level. Fewer studies have been conducted to determine differences between ethnicity/race. "Studies completed in the last three decades have shown that girls and boys have different interests and attitudes towards studying science" (Jones, Howe \& Rua, 2000). Therefore, these differences in interests and attitudes may affect their science test scores. Jones, Howe \& Rua (2000), conducted a study examining sixth grade students' attitudes and experiences related to science. Results indicated significant gender differences in science experiences, attitudes, and perceptions of science courses. Males reported more extra experiences with a variety of tools such as batteries, 
electric toys, fuses, microscopes, and pulleys. Females reported more experiences with bread-making, knitting, sewing, and planting seeds. Students' perceptions of science showed that significantly more females than males reported that science was difficult to understand, whereas more males reported that science was destructive and dangerous as well as more suited for boys (p.180). According to (Meece \& Daniels, 2008), "Differences by gender in students' science abilities are not consistent across age groups and content areas. On general tests of science achievement, there are few gender-related performance differences at the elementary school level. Differences in science abilities between girls and boys begin to occur in middle school and increase as students progress in school" (p.238).

According to Meece and Daniels (2008), "The ethnic and racial composition of American schools is rapidly changing. Over two-thirds of the students in U.S. public schools are likely to be a member of an ethnic minority group by the year 2010. The changing racial and ethnic backgrounds of America's school children will have profound implications for education in the future. Research indicates that children from minority ethnic groups score lower on many tests of cognitive ability than do their non-Hispanic, white classmates. The major exceptions to this pattern are Asian American children, who tend to perform better on tests of quantitative abilities than white children" (p.233). These patterns are not an indication of lack of ability on the part of the students from minority ethnic groups, but instead, they reveal the need for more diverse teaching methods. "In science, achievement gaps are considerably larger, and there has not been much change in the size of the achievement gap from the early 1980s. Because most schools reflect a white middle-class culture, ethnic minority children experience a number of problems when they enter school. Non-English-speaking children struggle the most, because they must master a new language before they can fully participate in learning activities in most schools" (Meece \& Daniels 2008, p.234). Chen and Pajares, (2010) investigated the association of implicit theories and epistemological beliefs and their effects on the academic motivation and achievement of 508 students in Grade 6 science. "Results of the study suggest that, when controlling for previous achievement, Hispanic students ascribe to more naïve beliefs about the certainty of scientific knowledge compared to their Asian, White and African-American peers. Hispanic students and Asian students ascribed to more naïve beliefs about the source of scientific knowledge, compared to their African American and White peers" (p.84). Therefore, Blacks and Hispanics may have lower test scores because of cultural disparities. "These cultural differences can lead to adjustment and achievement problems for ethnic minority students if the behaviors are interpreted as unacceptable, inappropriate, or "odd" by teachers or peers" (Meece and Daniels, 2008, p. 236).

\section{Design and Method}

Participants were sixth grade middle school students from four regular education science classes (Periods 1, 2, 3, and 5). English Language Learners (ELL) and special needs students were mainstreamed into each class. There were a total of 91 students in the four science classes. This study evaluated 77 students (33 females and 44 males) who completed both the pre-tests and post-tests. Fourteen students were eliminated from the study due to absences from the pre-test or post-test. The majority race participants were $45 \%$ white (See Table 1). Period One had a total of twenty-one students who completed the pre- and post- tests (8 females and 13 males) (See Table 2). The majority race participants were $52 \%$ white (See Table 3). Period Two had a total of seventeen students who completed the pre- and post- tests $(8$ females and 9 males) (See Table 4). The majority race participants were 47\% white (See Table 5). Period Three had a total of eighteen students who completed the pre- and post- tests (5 females and 13 males) (See Table 6). There were equal numbers $(50 \%)$ of Black and white students (See Table 7). Period Five had a total of twenty-one students who completed the pre- and post- tests (12 females and 9 males) (See Table 8). The majority race participants were $76 \%$ white (See Table 9).

\section{Instrument}

The pre- and post-tests consisted of a body outline with the nine endocrine glands in place. (See Appendix A) This instrument was an updated version of the endocrine test designed by the district, as required by state Science Standard 2 and Benchmark A. Science Standard 2 states that students can understand concepts and relationships in life science. Benchmark A states that students can understand the structures of living things. Students used a word bank to label the glands. Students, also, matched the glands with their functions in the body (See Appendix A) 


\section{Procedures}

Five days of lessons were taught beginning with a pre-test, followed by an introduction to the endocrine system, which stimulates the physical changes students experience as they reach adolescence. Power points were used to show students the names and locations of the nine endocrine glands in lifelike body images. A study worksheet of a body outline including the labeled endocrine glands and their functions in the body was given to students to help them prepare for the test. Daily, the teacher led the students in a "Simon Says" activity to practice pointing to the general area of the glands in their own bodies, with the help of worksheets, if needed. Days 2, 3, and 4 added a Pairs/Share review of the gland locations in the body, a reading worksheet of the endocrine system with comprehension questions, a framing worksheet for students to organize the endocrine glands and their functions, a "pizza" activity with the functions on the 'slice' to be matched with the name of the gland on the 'crust', enlarged body outlines with the glands in place on which students matched the names and functions to the glands on the body with partners. There was, also, a review sheet for students to match the glands with their functions. Day 5 added a matching review of the glands and functions using the ActivStudio smart board. Students moved the names and functions to the glands positioned in a body outline. Other students made corrections to the matches, if necessary. After the "Simon Says" review, students completed the post test (See Appendix A).

\section{Results}

Data for this study was analyzed using the SPSSPC, version 13. Three statistical tests were performed: descriptive statistics, t-tests and ANOVA. A comparison using an independent samples t-test was made for preand post-test science mean scores of male and female students. Results indicated no significant difference between male and female students' pre-test scores was found $(\mathrm{t}(75)$ $=-.346, \mathrm{p}>.05)$. The male mean pre-test score $(\mathrm{m}=$ 26.01, $\mathrm{sd}=17.64$ ) was not significantly different from the female mean pre-test score $(\mathrm{m}=22.21$, $\mathrm{sd}=16.98)$. Results indicated no significant difference between male and female students' post-test scores was found $(\mathrm{t}(75)=-.814$, $\mathrm{p}>$.05) (See Table 10). The male mean posttest score $(\mathrm{m}=71.02$, $\mathrm{sd}=21.50)$ was not significantly different from the female mean post-test score $(\mathrm{m}=$ 72.21, sd $=$ 22.23) (See Figure 1).
A paired-samples t-test was performed to compare science students' mean pre-test scores and post-test scores. A significant increase from pre-test to post-test scores was found $(\mathrm{t}(76)=-16.20, \mathrm{p}<.05)$ (See Table 11). The mean on the pre-test was $(\mathrm{m}=24.33$, sd $=17.35)$, and the mean post-test score was $(\mathrm{m}=71.53$, sd $=21.68)$ (See Figure 2).

An ANOVA was performed to compare science students' pre- and post-test scores by race. Tukey HSD was used to determine the differences in students' preand post-test scores by race. A significant difference in pre-test scores was found $(\mathrm{F}(2,74)=3.99, \mathrm{p}<.05)$ (See Table 12). The analysis revealed that white students scored higher $(\mathrm{m}=28.34$, $\mathrm{sd}=17.04)$ than black students $(\mathrm{m}=17.06$, sd $=15.01)$ (See Figure 3). There was no significant difference between students by race on the post-test $(\mathrm{F}(2,74)=.222, \mathrm{p}<.05)($ See Figure 4$)$.

According to the Iowa Department of Education (2010), "Iowa has statewide mandated core content standards in reading, math, and science. They were enacted when the Iowa legislature passed Senate File 588 in 2007. The current science core content standards for Iowa are (1) Students can understand and apply skills used in scientific inquiry, (2) Students can understand concepts and relationships in life science, (3) Students can understand concepts and relationships in Earth/space sciences and (4) Students can understand concepts and relationships in physical science". This study conducted an evaluation of the endocrine system, which addresses Iowa Science Standard 2: Students can understand concepts and relationships in life science. In this study it was hypothesized that:

1. There is no significant difference in pre-and post-test scores of science students.

2. There is no significant difference in pre-and post-test scores of science students by race.

3. There is no gender difference in pre-and post-test scores of science students.

The hypotheses were answered by analyzing $6^{\text {th }}$ grade students pre-test and post-test scores of the Endocrine System Test, which consisted of a body outline with the nine endocrine glands in place (See Appendix A). The findings of this study indicate that: 
- There was a significant increase in scores from the pre-test to the post-test.

- There were significant differences in pre-test scores by race, (white students scored higher than Black students) however, there were no significant differences in the post-test scores.

- Overall, there were no differences in scores by gender on the pre-test or the post-test. Girls may not have the same science background as boys, in general, but that does not impede their abilities to learn science curriculum. This is confirmed through a review of current literature and the results of this study.

The short and long term recommendations would support a better understanding of factors that affect the ability of students to learn about physical changes in their bodies. Some students are not comfortable discussing changes in their bodies in mixed gender classes, particularly, with references to the reproductive system. Teachers can make adjustments by allowing same gender groups during class activities and discussions. It is, also, imperative that teachers require of students respectful behaviors and language inside and outside the classroom learning environment. In conclusion, this study shows the need for pre- and post-testing to evaluate curriculum and teaching practices. Noting the significant difference in pre-test scores by race, but no significant difference in the post-test scores indicates that effective teaching does help schools minimize the achievement gap by race. Stanovich and Stanovich (2003) states, "there is evidence that children experiencing academic difficulties can achieve more educationally if they are taught with effective methods; sadly, scientific research about what works does not usually find its way into most classrooms" (p. 2). According to Stanovich and Stanovich (2003), "demonstrating student learning may seem like a simple task, but reflection reveals that it is a complex challenge requiring educators to use specific knowledge and skills. The curriculum must represent the most important knowledge, skills, and attributes that schools want their students to acquire because these learning outcomes will serve as the basis of assessment instruments. Likewise, instructional methods should be appropriate for the designed curriculum. Teaching methods should lead to students learning the outcomes that are the focus of the assessment standards" (p. 1).

Table 1. Demographic Characteristics of Sample $(\mathbf{N}=77)$.

\begin{tabular}{lll}
\hline Variables & & \% of Sample \\
\hline \multirow{2}{*}{ Gender } & Male & 44.9 \\
& Female & 33.7 \\
Age & & \\
& Eleven Years & 30.6 \\
& Twelve Years & 44.9 \\
Race & Thirteen Years & 3.1 \\
& & \\
& Black & 27.6 \\
& White & 44.9 \\
& Hispanic & 5.1 \\
& Asian & 1.0 \\
\hline
\end{tabular}


Table 1. Demographic Characteristics of Sample $(\mathbf{N}=77)$.

\begin{tabular}{lll}
\hline Variables & & \% of Sample \\
\hline \multirow{2}{*}{ Gender } & & \\
& Male & 44.9 \\
& Female & 33.7 \\
Age & & \\
& Eleven Years & 30.6 \\
& Twelve Years & 44.9 \\
Race & Thirteen Years & 3.1 \\
& & \\
& Black & 27.6 \\
& White & 44.9 \\
& Hispanic & 5.1 \\
& Asian & 1.0 \\
\hline
\end{tabular}

Table 2. Period 1: Mean Score - Gender $(\mathbf{N}=21)$.

\begin{tabular}{lccl}
\hline & $\mathrm{N}$ & Pre-test & Post-test \\
\hline Male & 13 & 32 & 66 \\
Female & 8 & 19 & 70 \\
\hline
\end{tabular}

Table 3. Period 1: Mean Score - Race and Gender $(\mathrm{N}=21)$.

\begin{tabular}{|c|c|c|c|}
\hline & Pre-test & Post-test & $\%$ of $\mathrm{N}$ \\
\hline \multicolumn{4}{|l|}{ Female } \\
\hline Black & 12 & 68 & $19 \%$ \\
\hline White & 26 & 72 & $19 \%$ \\
\hline \multicolumn{4}{|l|}{ Male } \\
\hline Black & 9 & 75 & $23.8 \%$ \\
\hline White & 33 & 58 & $33.3 \%$ \\
\hline Hispanic & 16 & 72 & $4.8 \%$ \\
\hline \multicolumn{4}{|l|}{ Total } \\
\hline Black & 10 & 72 & $42.9 \%$ \\
\hline White & 30 & 63 & $52.4 \%$ \\
\hline Hispanic & 16 & 72 & $4.8 \%$ \\
\hline
\end{tabular}


Table 4. Period 2: Mean Score - Gender $(\mathrm{N}=17)$.

\begin{tabular}{llll}
\hline & N & Pre-test & Post-test \\
\hline Male & 9 & 33 & 76 \\
Female & 8 & 26 & 79 \\
\hline
\end{tabular}

Table 5. Period 2: Mean Score - Race and Gender $(\mathbf{N}=17)$.

\begin{tabular}{lllll}
\hline & & Pre-test & Post-test & $\%$ of N \\
\hline Female & & & & \\
& Black & 27 & 77 & $17.6 \%$ \\
& White & 38 & 88 & $11.8 \%$ \\
& Hispanic & 16 & & $17.6 \%$ \\
& & & & \\
Male & & 94 & $11.8 \%$ \\
& Black & 35 & 67 & $35.3 \%$ \\
& White & 29 & & $5.9 \%$ \\
& Asian & 50 & & \\
& & & 84 & $29.4 \%$ \\
Total & & 73 & $47.1 \%$ \\
& Black & 71 & 88 & $17.6 \%$ \\
& White & 32 & & $5.9 \%$ \\
& Hispanic & 16 & & \\
& Asian & 50 & &
\end{tabular}

Table 6. Period 3: Mean Score - Gender $(\mathrm{N}=18)$.

\begin{tabular}{llll}
\hline & N & Pre-test & Post-test \\
\hline Male & 13 & 18 & 73 \\
Female & 5 & 12 & 64 \\
\hline
\end{tabular}


Table 7. Period 3: Mean Score - Race and Gender $(\mathrm{N}=18)$.

\begin{tabular}{|c|c|c|c|}
\hline & Pre-test & Post-test & $\%$ of $\mathrm{N}$ \\
\hline \multicolumn{4}{|l|}{ Female } \\
\hline Black & 15 & 61 & $22.2 \%$ \\
\hline White & .05 & 77 & $5.6 \%$ \\
\hline \multicolumn{4}{|l|}{ Male } \\
\hline Black & 14 & 70 & $27.8 \%$ \\
\hline White & 20 & 76 & $44.4 \%$ \\
\hline \multicolumn{4}{|l|}{ Total } \\
\hline Black & 15 & 65 & $50.0 \%$ \\
\hline White & 19 & 76 & $50.0 \%$ \\
\hline
\end{tabular}

Table 8. Period 5: Mean Score - Gender $(\mathrm{N}=21)$.

\begin{tabular}{lccc}
\hline & $\mathrm{N}$ & Pre-test & Post-test \\
\hline Male & 13 & 35 & 70 \\
Female & 5 & 26 & 72 \\
\hline
\end{tabular}

Table 9. Period 5: Mean Score - Race and Gender $(\mathrm{N}=21)$.

\begin{tabular}{|c|c|c|c|}
\hline & Pre-test & Post-test & $\%$ of $\mathrm{N}$ \\
\hline \multicolumn{4}{|l|}{ Female } \\
\hline Black & 13 & 62 & $14.3 \%$ \\
\hline White & 27 & 75 & $38.1 \%$ \\
\hline Hispanic & 55 & 77 & $4.8 \%$ \\
\hline \multicolumn{4}{|l|}{ Male } \\
\hline Black & 44 & 83 & $4.8 \%$ \\
\hline White & 34 & 68 & $38.1 \%$ \\
\hline \multicolumn{4}{|l|}{ Total } \\
\hline Black & 21 & 68 & $19.0 \%$ \\
\hline White & 31 & 72 & $76.2 \%$ \\
\hline Hispanic & 55 & 77 & $4.8 \%$ \\
\hline
\end{tabular}


Table 10. Independent Samples t-test: Pre \& Post Test Scores $(\mathbf{N}=77)$.

\begin{tabular}{lll}
\hline & Pre-test & Post-test \\
\hline Male & 26.01 & 71.02 \\
Female & 22.21 & 72.21 \\
\hline
\end{tabular}

Figure 1. Pre-/Post-Test Scores - Male/Female

Total Mean Male/Female Test Scores

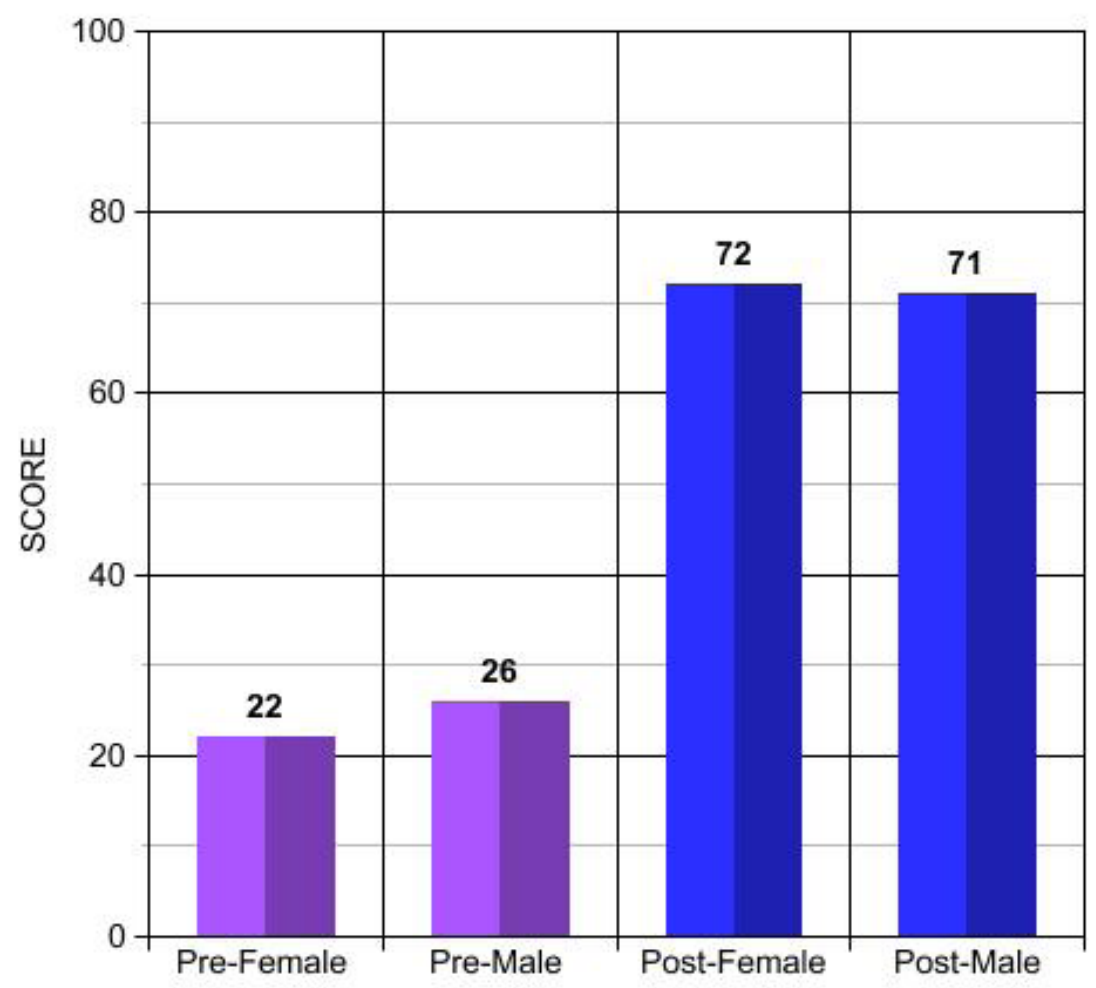

Table 11. Paired Samples t-test: Pre \& Post Test Scores $(N=77)$.

\begin{tabular}{lccccc}
\hline & M & SD & df & t & p \\
\hline Pretest & 24.38 & 17.35 & & & \\
Post-test & 71.53 & 21.68 & 76 & -16.201 & .000 \\
\hline
\end{tabular}

Note: Significant at $\mathrm{p}<.05$ level 
Figure 2. Mean Pre-/Post-Test Scores.

Total Mean Pre- \& Post Test Scores

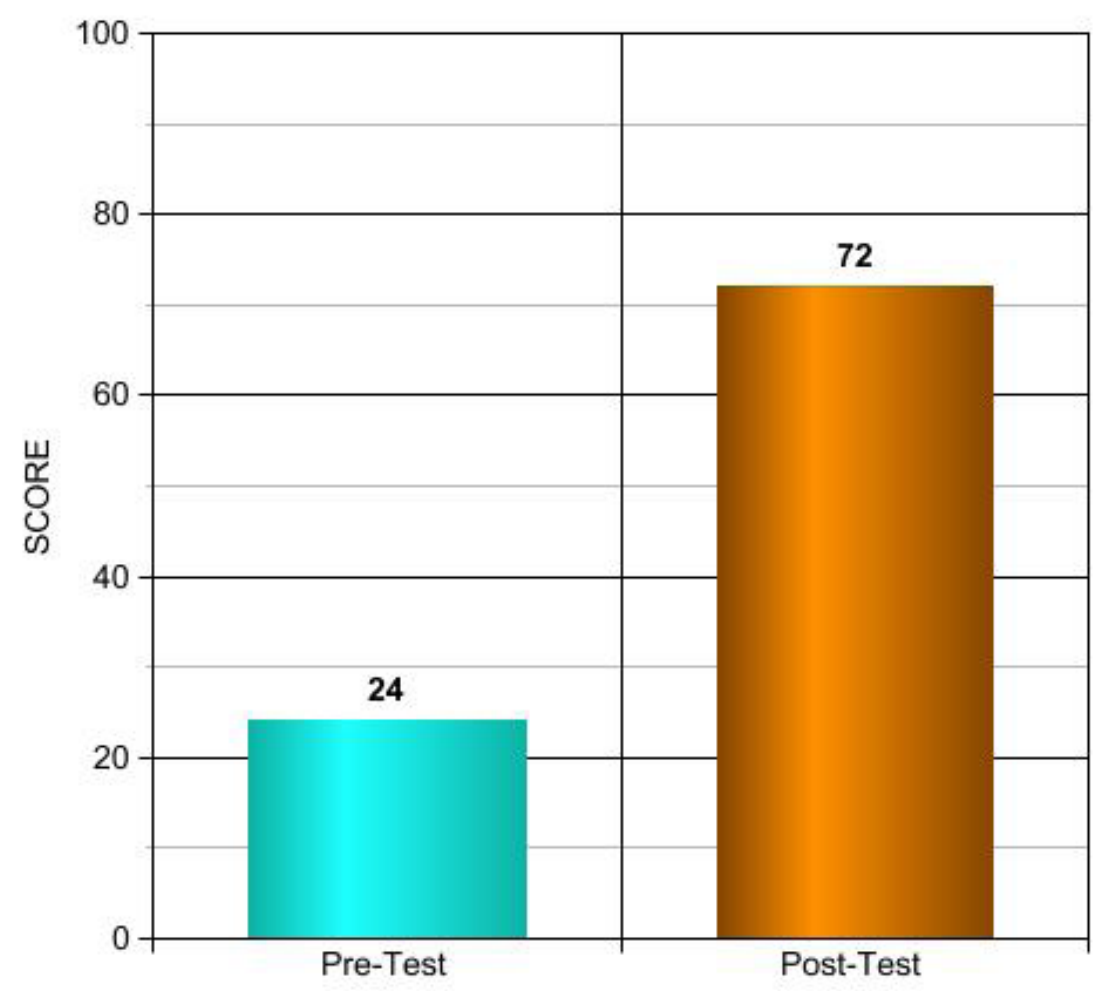

Table 12. Analysis of Variance (ANOVA) - Race $(\mathrm{N}=77$ ).

\begin{tabular}{lll}
\hline & F & Sig. \\
\hline Pre-test & 3.99 & .217 \\
Post test & .222 & .559 \\
\hline
\end{tabular}


Figure 3. Mean Pre-Test Scores - Race.

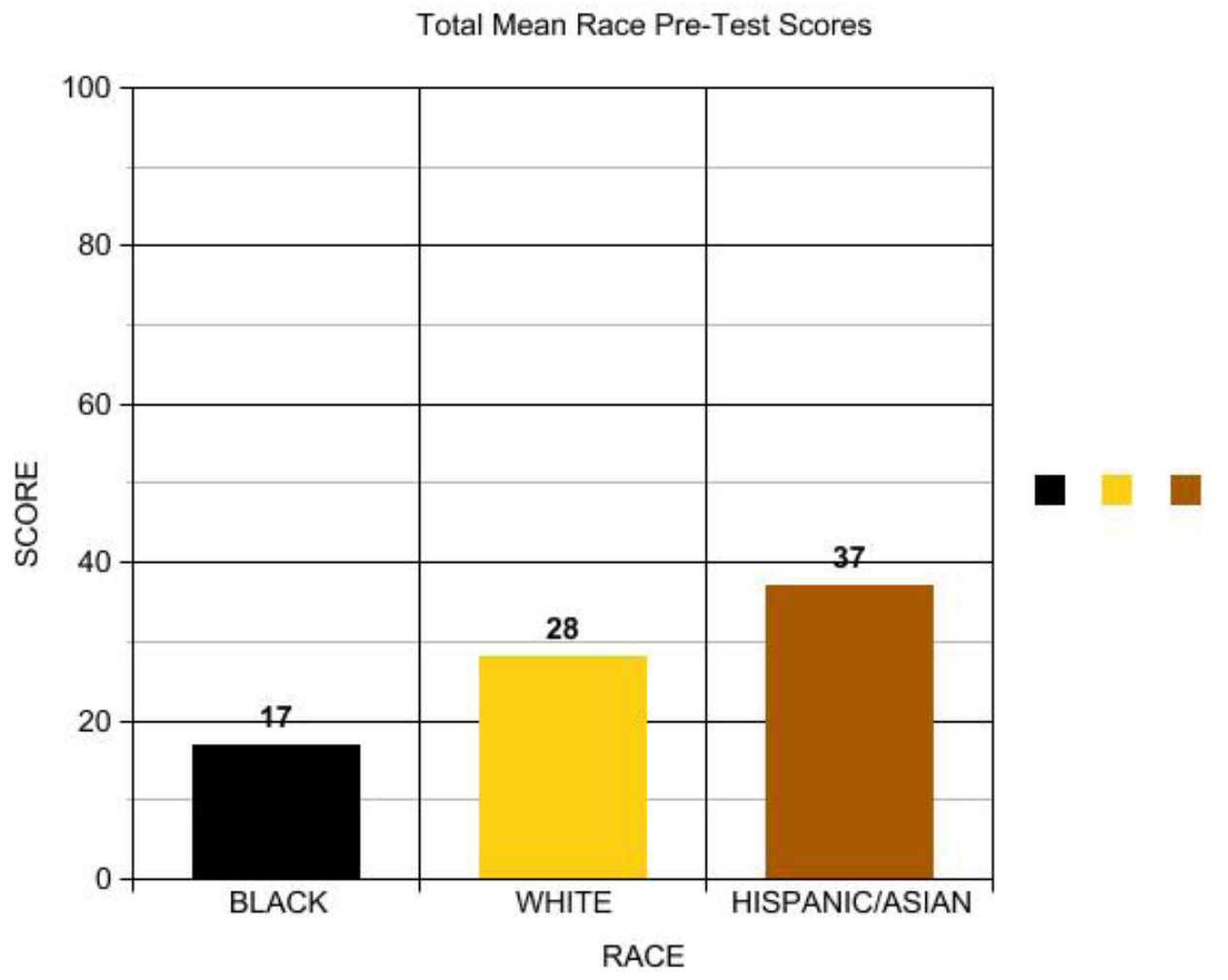

Figure 4. Mean Post-Test Scores - Race.

Total Mean Race Post-Test Scores

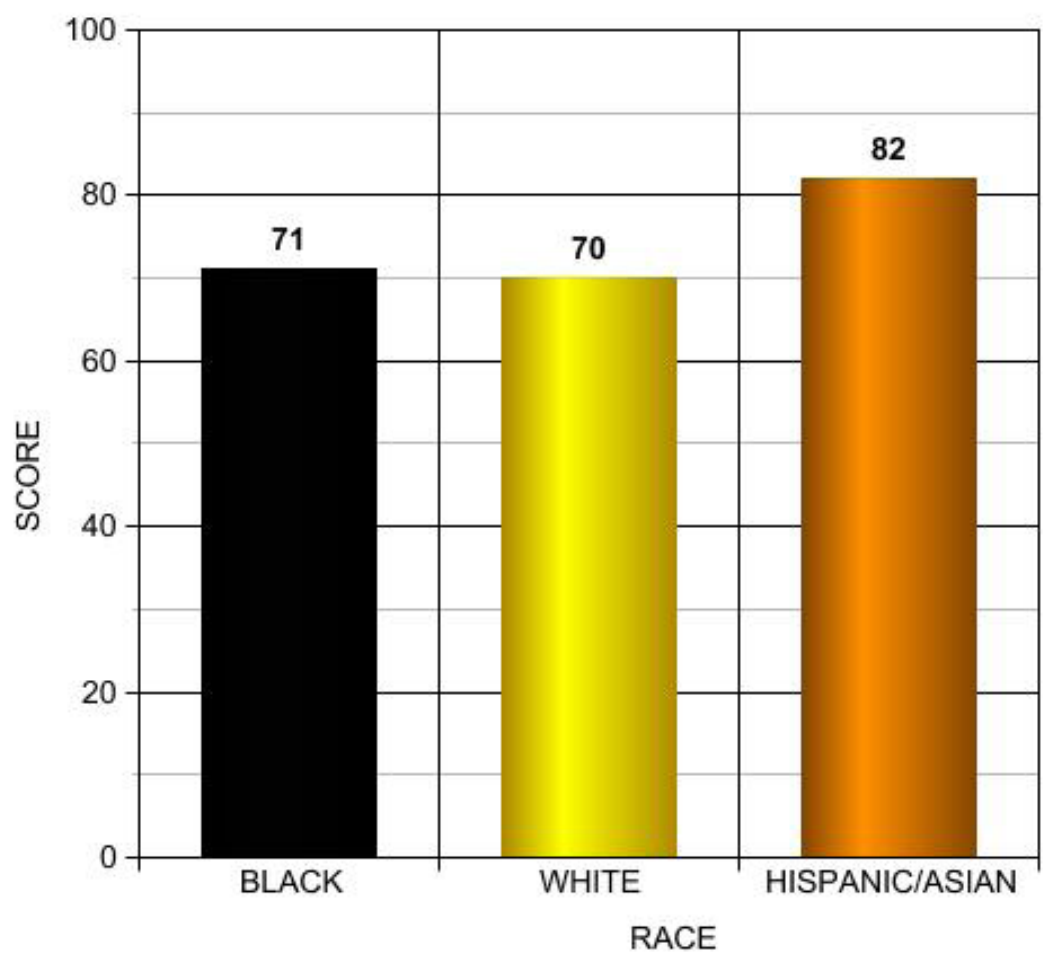




\section{Appendix A}

\section{Endocrine System Pre-Test}

Part 1: On each line, write the word that labels each endocrine gland using the word list below.

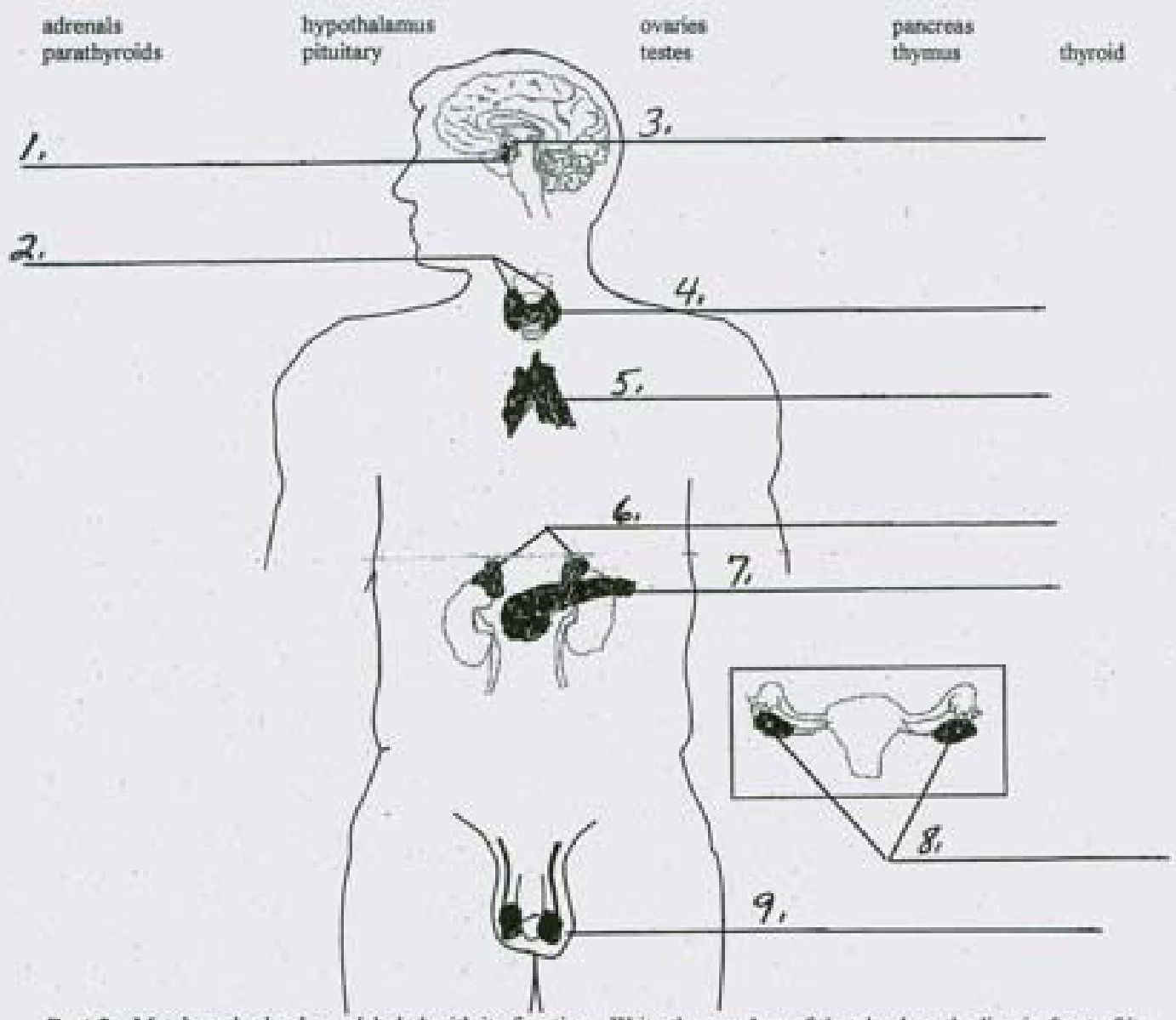

Part 2: Match each gland you labeled with its flunction. Write the ummber of the gland on the line in front of its function.

Controls endoctine glands $\&$ body growth

Stimulates the nervous vystem during emergencies

Controls metabolism; the release of energy

Coecrols the cate at which cells use

from food molecules

sagar in the blood

Controls the amount of calcium \&

Repulates female sexual

phosphorous in the blood

development and reprobsction

Controls immunities in ctildten

Regulates male sexual development and reproduction

Links the nervous and endocrine systems and coetrols the pituitary gland 


\section{Endocrine System Post-Test}

Part t: On each line, write the word that labels each endocrine gland using the word list below.

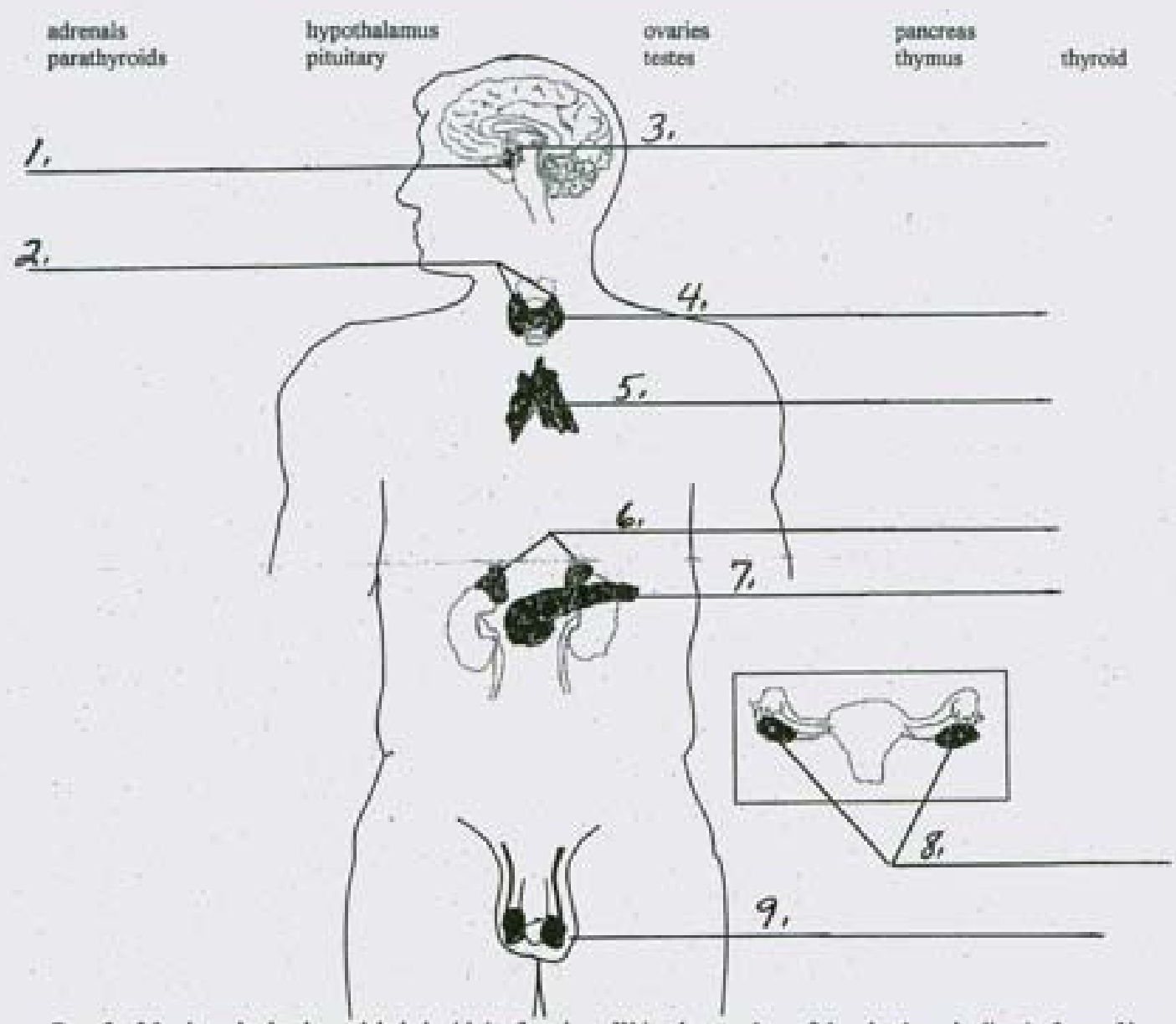

Part 2: Match each gland you labeled with its fiunction. Write the number of the gland on the line in front of its flunction.

Controls endocrine glands \& body growth

Controls methbolism; the release of energy

from food molecules

Controls the amount of calcium \&

phospborous in the blood

Controls immunities in ctilitren
Stimulates the nervous system during emergeneies

Controls the rate at which cells use sagar in the Blood

Regulates female sexual development and reproduction

Regulates male sexual development and reproduction

Links the nervosas and endocrine systems and controls the pituitary gland 


\section{References}

Bose, E. (2005). Test-Taking Tips for Children. Retrieved on October 20, 2010 from http://www.libraryvideo. com/guides/K6718.pdf

Chen, J,, Pajaries, F. (2010). Implicit Theories of Ability of Grade 6 Science Students: Relation to Epistemological Beliefs and Academic Motivation and Achievement in Science. Contemporary Educational Psychology, 35, $75-85$.

Iowa Department of Education. Retrieved on September 19, 2010 from http://www.iowa.gov/educate/ index.php?option=com_content $\&$ view $=$ article $\&$ id $=$ 1350\&Itemid $=2287$

Jones, M., Howe, A., Rua, M. (2000). Gender Differences in Students' Experiences, Interests, and Attitudes Towards Science and Scientists. Science Education, $84, \quad 2, \quad 180-192$.

Lee, O., Anderson, C. (1999). Task Engagement and Conceptual Change in Middle School Science Classrooms. American Educational Research Association Journal, 30, 3, 585 - 610.

Meece, J., Daniels, D. (2008). Child and Adolescent Development for Educators. McGraw-Hill Companies: New York, NY, 233-236.

National Research Council (1996). National Science Education Standards. National Academy Press, Washington, DC.

National Science Education Standards. Retrieved on September 10, 2010 from http://www.education world. com/standards/national/science/5_8.shtml

Stanovich, P.J., \& Stanovich, S.E. (2003). Using Research and Reason in Education: How Teachers Can Use Scientifically Based Research to Make Curricular \& Instructional Decisions. National Institute for Literacy. EdPubs, Jessup, MD
Stern, L., \& Ahlgren, A, (2002). Analysis of Students' Assessments in Middle School Curriculum Materials: Aiming Precisely at Benchmarks and Standards. Journal of Research in Science Teaching, 39, 9, 889 $-910$

Waterloo Community School District (2010). Central Middle School Annual Report 2009-2010. Retrieved October 8, 2010 from http://www.waterloo.k12.ia.us/ files/shcools/2009-10/central _09-10.pdf

Waterloo Community School District (2007). K-8 Science Standards and Benchmarks. Retrieved October 8, 2010 from http://www/waterloo.k12.us/teachinglearning/ index/php?pageid=204

Yager, R., \& Weld, J. (1999). Scope sequence and coordination: The Iowa Project, a national reform effort in the USA. International Journal of Science Education, 21, 2, 169-194.

\section{Correspondence:}

Jiangong Tan, Ed. D.

Department of Leisure and Sports Management Guangzhou Sport University

1268\#, Middle of Guangzhou Avenue

Guangzhou, 510500

P. R. China

Email : tanjiangong@yahoo.com

Phone : 86-20-87554327

Cell : 13539988352 